\title{
Quantifying the symbiont contribution to essential amino acids in aphids: the importance of tryptophan for Uroleucon ambrosiae
}

\author{
E. A. B ER NA Y S and B. A. K L E I N \\ Department of Entomology and Department of Ecology and Evolutionary Biology, University of Arizona, Tucson, U.S.A.
}

\begin{abstract}
A complete amino acid budget was constructed using the aphid Crrøleucon ambresiae (Strecker), feeding on a suboptimal host, Tithonia fruticosa. The availability of amino acids was estimated from phloem analyses and phloem intake rates at each stage of development. Requirements for amino acids were estimated from gravimetric studies and from analyses of body amino acids. Because the budget was found to be well balanced, estimates of specific needs and shortfalls of essential amino acids were calculated, thus quantifying the role of symbiotic bacteria in fulfilling needs for these amino acids. The most dramatic shortfall was for tryptophan, consistent with the amplification of relevant genes in the symbiont.
\end{abstract}

Key words. Bacterium, Buchnera, nutritional budget, phloem, stylectomy, symbiont, tryptophan.

\section{Introduction}

It is well established that aphids depend on their symbiotic Buchner bacteria to produce many essential amino acids that are at low concentrations in their food, the phloem sap of plants (Douglas, 1998; Sandstrom \& Moran, 1999). Various approaches have been used to show the importance of these bacterial symbionts for amino acid production. These have included performance studies using artificial diets (e.g. Dadd \& Krieger, 1968; Sandstrom, 1994; Douglas etal., 2001) artificially produced aposymbiotic aphids (e.g. Mittler, 1971; Prosser \& Douglas, 1991; Liadouze etal., 1995), radiotracer studies (e.g. Sasaki etal., 1993; Febvay etal., 1999), investigations of the symbiont genome (e.g. Lai et al., 1996) and studies of plant manipulation by feeding aphids (Telang et al., 1999; Sandstrom et al., 2000). However, although the concentrations of particular amino acids are known to vary considerably (Sandstrom \& Moran, 1999), less is known about the precise amounts of each that is required (Sandstrom, 2000). In a recent study using

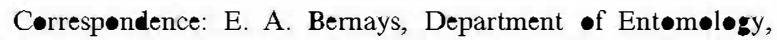

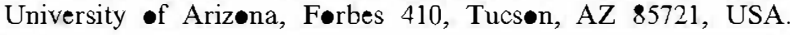
Tel. +1 5206211151; fax:+1 5206211150; e-mail: schistos@ as.arizøna.edu
Aphis fabae (Douglas et al., 2001), a comparison of symbiotic and aposymbiotic aphids fed on different synthetic diets with specific amino acids omitted, demonstrated differential productivity of essential amino acids by symbionts, indicating that there is regulation of the bacteria by aphid needs.

Some prior work has focused on the ability of symbionts to manufacture tryptophan and leucine, because of the unusual arrangements of the symbiont genes underlying these pathways and the large copy number of $\operatorname{trp} E G$ genes encoding the rate-limiting enzyme for its production. This suggests that tryptophan is an amino acid that may be needed in quantity by the fast-growing species that have been studied (Baumann etal., 1997). Loss of function in some of the $\operatorname{trp} E G$ gene copies has also occurred independently in several different aphid species, including Diuraphis noxia (Lai etal., 1996) and two species of Uroleucon (Baumann etal., 1997; Wernegreen \& Moran, 2000; Wernegreen etal., 2001), consistent with variable need for tryptophan among species. Similarly, endosymbionts from different aphid species may have different copy numbers of the plasmid containing the leucine biosynthetic genes (Thao etal., 1998).

Our study investigates amino acid budgets in Ureleucon ambresiae (Strecker), a species that feeds solely or preferentially on the herbaceous composite Ambresia trifida over much of its range (Moran, 1985). Uroleucon ambrosiae is 
cyclically parthenogenetic, producing sexuals in the autumn, and generally overwintering in the egg stage. In Arizona, this species feeds on a variety of plants in the Asteraceae (Funk \& Bernays, 2001), including the woody perennial Tithonia fruticesa. Although suboptimal for growth, this plant can provide a resource in the xeric south-west United States and Mexico at times when the preferred herbaceous hosts are scarce or unavailable, and it also supports asexual clones through the winter in southern Arizona.

Previous studies of nutrition in aphids have focused on species that are pests of agricultural crops that feed on fastgrowing annual plants. Furthermore, budgetary approaches have invariably made use of young seedlings of hosts growing under rich nutrient conditions. Such favoured hosts, which allow very high growth rates, are unlike the plants that many aphids feed on for much of their life cycle plants that grow slowly, are in a relatively unsuitable phenological stage or state of nutrition, or species that are otherwise suboptimal. It may be expected that the evolution of symbiont biosynthetic capabilities will partially reflect these non-optimal conditions.

Here, a complete budget for amino acids is calculated from amino acid analyses of the food, quantities of ingested food, measurements of growth including exuviae production and birth rate of nymphs, and analysis of major body constituents. The data resulted in balanced budgets for total amino acids, allowing the following questions to be asked. Which amino acids are ingested in smaller quantities than required for observed growth? What is the minimum quantity of each limiting essential amino acid that must be produced by the symbiotic bacteria? How do the relative proportions of limiting essential amino acids vary in the host? The data are discussed in relation to the numbers of bacterial symbionts, and their genes for biosynthesis of the critical essential amino acids.

\section{Materials and methods}

Ureleucon ambresiae were collected in the autumn of 1999 from a single 20 -year-old plant of Tithonia frutices growing on the campus of the University of Arizona. Individuals were transferred to 2-year-old potted plants obtained from a local nursery. Aphids were allowed to establish on these plants in a greenhouse maintained at approximately $25^{\circ} \mathrm{C}$. All tested adults were parthenogenetic apterae of unknown age, although some of the nymphs used were destined to become alatae. Where adults were selected specifically for measurements, we chose the largest individuals that were producing young.

Most procedures involving growth, reproduction, water loss and honeydew sampling were carried out in a second greenhouse at approximately $22^{\circ} \mathrm{C}$, whereas collection of leaf exudates and phloem occurred in the laboratory but at average temperatures of $22^{\circ} \mathrm{C}$. The diversity of measurements generally involved groups of aphids from one plant, and each type of measurement usually necessitated the use of separate individuals or groups of individuals. No aphid was used for more than one measurement of any kind. Thus, the budget elements were constructed from mean values. A budget that is balanced to within approximately $10 \%$, using many independent measures, should provide the confidence that errors were limited, although the normal use of variance is not an option with these experiments. However, where possible, indications of variation and their impact on the budget estimates are shown.

All data used in the development of budgets were collected in the autumn of $\mathbf{2 0 0 0}$ within a period of 2 months. Conditions in the greenhouse were standardized except that daylength was decreasing. The $T$. frutices plants were watered and provided with nutrients (in the form of Osmocote), but showed little growth or change in gross appearance during the test period.

\section{Volume of phloem ingested}

Phloem ingestion was estimated indirectly, by summing the volume of honeydew produced, the water lost by transpiration, and the added body weight during growth.

Single honeydew drops were collected immediately from isolated individuals of first, second, third and fourth stadium nymphs and adult apterae feeding on $T$. frutices in the greenhouse. When they fell into a dish of liquid paraffin held immediately under the leaf, these drops maintained their spherical shape, allowing their diameters to be measure using a Wild stereomicroscope with an eyepiece micrometer. From the radius, the volume was then calculated. Drop sizes from individuals were remarkably constant, as has been found by others (e.g. Fisk, 1978), so one drop was used from each of a number of different individuals. Drops were collected from $6,8,12,10$ and 16 aphids used for the different life stages (first stadium to adult apterae).

Rates of honeydew production were measured separately to obtain data over longer periods than for drop size measurement. This was done by collecting drops from individuals onto indicator paper. A $T$. frutices plant was arranged such that four individual leaves extended over a 20-cm circle of Whatman chromatography paper. This paper was impregnated with $1 \%$ bromocresol blue at pH 6, a yellow dye that turns blue when struck by honeydew. The circle of paper rested on a Plexiglas plate attached to a clock mechanism so that the paper rotated once in $24 \mathrm{~h}$. Because each aphid was set at a different distance from the centre, honeydew production from four aphids could be monitored simultaneously. In practice, 24-h measurements were never achieved due to movement of aphids or plant, but in all cases at least $6 \mathrm{~h}$ was used to estimate the daily production rate, and the 6-h periods spanned the 24-h cycle. There were two, four, five, six and eight aphids used to evaluate different life stages (first to adult).

Volumes of honeydew produced per day and per stadium were calculated from average drop sizes, average number of drops per hour, and the average durations of the different 
life stages. Averages were used because different individual aphids were used for all these measurements.

Water loss from $U$. ambresiae was measured by weight loss, assuming that the weight loss of aphids that were not feeding or producing honeydew was due to transpiration (Banks \& Macaulay, 1964). Individuals of each stadium were removed carefully from plants for $1 \mathrm{~h}$ (to allow for the cessation of honeydew production), then weighed on a microbalance sensitive to $0.1 \mu \mathrm{g}$ before being returned to their host plants. Each individual was touched gently at intervals of approximately $10 \mathrm{~min}$ to make it walk, ensuring that it could not feed. After times varying from 1 to $3 \mathrm{~h}$ the individuals were again weighed. Weight loss was multiplied by the appropriate amount to estimate water loss per day. Determinations were made for 10 first-stadium nymphs measured as a group, five second-stadium nymphs measured as a group, and three individuals each of third- and fourth- stadium nymphs and adults. Average relative humidity was $70 \%$.

Weight increases were taken from the gravimetric study (see below).

\section{Amin acid uptake}

Amino acid concentrations were measured in samples of phloem and from leaf exudates. The latter provided additional information on the degree of variation in proportions of individual amino acids present. Amino acid concentrations in honeydew were analysed to determine the proportion of amino acids excreted or not absorbed, with some additional data from dried honeydew on variation in the proportions of individual amino acids. Amounts of amino acids required for exuviae and growth were evaluated separately.

Amino acid composition of samples was determined using a dedicated Beckman 7300 Analyser (Beckman Instruments Inc., Fullerton, CA, U.S.A.; ion-exchange ninhydrin). Concentrations of amino acids were calculated from peak heights compared with an external standard. Only protein amino acids were considered in most of this work. However, some others such as ornithine and $\beta$-alanine, were observed at very low concentrations and varied little. One non-protein amino acid, $\gamma$-aminobutyric acid (GABA), reached relatively high levels in the leaf exudates but not in phloem from stylectomies or in aphids or honeydew. The non-protein amino acids were ignored. Amino acids defined as essential in this study are those considered essenial for animals in general (Bender, 1985) including insects not dependent on symbionts for their production (Dadd, 1977) - arginine, histidine, isoleucine, leucine, lysine, methionine, phenylalanine, threonine, tryptophan and valine.

Three phloem samples were obtained by stylectomy from leaves of $T$. frutic s that were subsequently used to obtain leaf exudates (see below). One plant, having 10-60 adult apterae and young feeding on each leaf, was used for this study. The plant was prepared by placing it in a room dedicated to stylectomy and kept at $22^{\circ} \mathrm{C}$ and $>90 \%$ r.h.
After $1-2 h$, leaves were fixed in a manner that allowed a frontal view of a feeding aphid with a Leitz stereomicroscope and fibre optic illumination. A high frequency microcautery device (Model CA-50, Syntech Inc., the Netherlands) was used for stylet cutting, and emergent phloem was collected into microcaps $(0.5 \mu \mathrm{L})$. When sample volumes reached $30-100 \mathrm{~nL}$ as measured with a micrometer eyepiece, they were dispensed into microcentrifuge tubes containing $100 \mu \mathrm{L}$ lithium buffer (lithium citrate, LI-S System $7300 / 6300$ high performance amino acid sample dilution buffer, Beckman) and stored at $-20^{\circ} \mathrm{C}$ until analysis.

Data from stylectomies of aphids feeding on $T$. frutices were compared with those from exudates of the same leaves. Exudates of additional leaves of $T$. frutices in spring and autumn were also analysed to investigate variation in the proportions of amino acids present. Leaf exulates were obtained by collection into EDTA. Leaves were brushed free of aphids, excised in a solution of $8 \mathrm{mM}$ EDTA (brought to $\mathrm{pH} 7.0$ with $1 \mathrm{M} \mathrm{KOH}$ ) and within $5 \mathrm{~min}$ recut in the solution and immersed in $100 \mu \mathrm{L}$ fresh EDTA solution in individual $0.5 \mathrm{~mL}$ microcentrifuge tubes. The opening of each vial around the leaf was wrapped with cling film and all samples kept in an airtight plastic box containing water in the dark at room temperature $\left(24^{\circ} \mathrm{C}\right)$ for $c$. $6 \mathrm{~h}$ (Telang etal., 1999). After collection, samples were centrifuged to remove any debris and an aliquot removed and diluted 1: 1 with lithium buffer. This was stored at $-20^{\circ} \mathrm{C}$ until analysis. In spring, six separate leaves from two plants of $T$. frutices were examined. In autumn, five separate leaves from one plant were examined, three of which had been used to sample phloem using aphid stylectomy.

Groups of nymphs and adult apterae were enclosed in an aphid clip cage on the underside of a leaf of a $T$. frutices plant kept in a lighted room at $24^{\circ} \mathrm{C}$. After the aphids were settled, the screen cover of the cage was replaced with a cone-shaped container (the tip of a $200 \mathrm{~mL}$ Teflon centrifuge tube) containing hexadecane, into which honeydew drops fell and coalesced. After approximately $5 \mathrm{~h}$, the honeydew $(c .500 \mathrm{~nL})$ was removed with a microcap and diluted with lithium buffer $1: 1$ and stored at $-20^{\circ} \mathrm{C}$ until analysis. Four such samples were obtained using four leaves from the same plant used for stylectomies.

Dried honeydew was also collected from groups of aphids feeding on $T$ : frutices . Clean Petri dishes were suspended below groups of aphids on the plant and after $24 \mathrm{~h}$ dishes containing the dried drops of honeydew were removed by repeated rinsing with $200 \mu \mathrm{L}$ lithium buffer. The washings were kept at $-20^{\circ} \mathrm{C}$ until analysis. Samples were collected from aphids on five different leaves in the spring and two in the autumn. These data provide some measure of variation in proportions of different amino acids lost in honeydew, although they cannot inform about concentrations.

\section{Amin acid requirements}

A gravimetric study was carried out first. Aphids, firstfourth stadium nymphs and adults, were weighed on a Cahn 
microbalance, sensitive to $0.1 \mu \mathrm{g}$. The duration of each instar was monitored on 10 individuals and the number of young produced per day was monitored on 20 adult apterae of unknown age. All measurements were performed in a greenhouse on the same plants used for other measurements. Temperatures varied from 18 to $24^{\circ} \mathrm{C}$ but averaged $22^{\circ} \mathrm{C}$.

Production of nymphs over three days by 20 individual aphids was determined. This averaged $0.9 \pm 0.2$ nymphs/day.

For body analyses, water and lipid content were measured on approximately 50 aphids weighed together, dried at $50^{\circ} \mathrm{C}$ for $24 \mathrm{~h}$ and reweighed to obtain percentage dry weight. They were then extracted with a 1:1 mixture of chloroform and ethanol to remove lipids (Prosser \& Douglas, 1991) and reweighed to estimate percentage lipid content. The remaining weight was assumed to be $75 \%$ protein. This allows for the contained sugars and the chitin in cuticle (Anderson, 1973), as well as minerals (ash) (Van Hook et al., 1980).

Amino acid content of the body was examined by grinding aphids in $100 \mu \mathrm{L}$ saline $(25 \mathrm{~g} / \mathrm{L} \mathrm{KCl})$ with a pestle and mortar, centrifuging and diluting a sample of the supernatant $1: 1$ with lithium buffer. Samples were then stored at $-20^{\circ} \mathrm{C}$ until analysis. In spring, 10 samples were obtained, and in the autumn four samples were obtained. Such samples contain free amino acids in the haemolymph, as well as those present in the gut and other tissues. One additional sample of haemolymph was obtained by cutting off the antennae from four individual adults and gently squeezing the aphids in order to collect approximately $200 \mathrm{~nL}$, which was placed in $100 \mu \mathrm{L}$ lithium buffer and stored at $-20^{\circ} \mathrm{C}$ until analysis.

Exuviae (four to six) of stadia two, three and four were collected from the culture, dried and weighed on a Cahn microbalance. They were assumed to average $40 \%$ protein (including tyrosine-derived phenols needed for sclerotization). This value is an estimate based on the work of Van Hook etal. (1980), who measured nitrogen in exuviae of the aphid Macresiphum liriedendri at $4.61 \%$ of the total mass.

Published data were also used. Sandstrom \& Moran (2001) and Febvay et al. $(1988,1995,1999)$ provided information on the amino acid constituents of aphid proteins, including tryptophan, in $\mathrm{nmol} / \mathrm{mg}$ fresh body weight, and these values were used in this work as an independent measure of needs. Because the differences among species were relatively small, an overall average of the different profiles was taken.

\section{Results}

Estimate of volumes of phloem ingested

Estimates of loss of water by transpiration, and of honeydew production derived from the data are given in Table 1. The water content of the body increases from
Table 1A. Water løss estimates. Weight løss.

\begin{tabular}{|c|c|c|c|c|}
\hline Stadium & $n$ & $\begin{array}{l}\text { L॰ss } / \mathrm{h} \\
(\mu \mathrm{g})\end{array}$ & $\begin{array}{l}\text { Days in } \\
\text { stadium }\end{array}$ & $\begin{array}{l}\text { T॰tal løss/insect } \\
(\mu \mathrm{g})\end{array}$ \\
\hline 1 & 1 (1) in sample) & 5.4 & 2 & $259 /$ instar \\
\hline 2 & 1 (5 in sample) & 13.8 & 3 & 994/instar \\
\hline 3 & 3 & $25.9 \pm 1.0$ & 3 & 1865/instar \\
\hline 4 & 3 & $31.3 \pm 1.1$ & 4 & $\begin{array}{l}3005 / \text { instar } \\
6123 / \text { t•tal grøwth }\end{array}$ \\
\hline Adult & 3 & $19.2 \pm 0.9$ & - & $46 /$ insect/day \\
\hline
\end{tabular}

Table 1B. Water loss estimates. Høneydew prøduction.

\begin{tabular}{|c|c|c|c|c|}
\hline Stadium & $n$ & $\begin{array}{l}\text { Drøp vølume } \\
(\mathrm{nL})\end{array}$ & $\begin{array}{l}\mathrm{N} \bullet \text { dr॰ps/ } \\
24 \mathrm{~h}\end{array}$ & $\begin{array}{l}\text { T॰tal/insect } \\
(\mathrm{nL})\end{array}$ \\
\hline 1 & 6,2 & $14 \pm 4$ & $9 \pm 4$ & 252 \\
\hline 2 & 8,4 & $31 \pm 5$ & $11 \pm 3$ & 1023 \\
\hline 3 & 12,5 & $6 \pm 5$ & $10 \pm 3$ & 1800 \\
\hline 4 & 10,6 & $78 \pm 6$ & $12 \pm 3$ & $\begin{array}{l}3744 \\
6819 / \text { total grøwth }\end{array}$ \\
\hline Adult & 16,8 & $92 \pm 2$ & $10 \pm 5$ & $920 /$ day \\
\hline
\end{tabular}

89 to $1183 \mathrm{~nL}$ (Table 2), an increase of $1094 \mathrm{~nL}$. Water intake of the individual is determined as:

$$
\begin{gathered}
\text { Intake }=\text { increase in body water }+ \text { water lost in } \\
\text { transpiration }+ \text { water in honeydew }
\end{gathered}
$$

Thus, during development:

$$
\text { water intake }=1094+6123+6819=14036 \mathrm{~nL}
$$

An adult aptera produces an average of 0.9 nymphs/day, each with an average water content of $89 \mathrm{~nL}$. Thus, on a daily basis an adult female's daily water requirements are:

$$
80 \text { (for nymph production) }+460 \text { (transpiration) }+920
$$$$
\text { (honeydew) }=1460 \mathrm{~nL}
$$

Table 2A. Majør nutrient constituents of aphids in different stadia, based $\bullet$ six $\bullet$ each føurth instar and adult aphids and grøups of newbørn first instars.

\begin{tabular}{llclcc}
\hline Stadium & $\begin{array}{l}\text { Fresh wt } \\
(\mu \mathrm{g})\end{array}$ & $\begin{array}{l}\text { Dry wt } \\
(\mu \mathrm{g})\end{array}$ & $\begin{array}{l}\text { Water } \\
(\mathrm{nL})\end{array}$ & $\begin{array}{l}\text { Lipid } \\
(\mu \mathrm{g})\end{array}$ & $\begin{array}{l}\text { Pr tein* } \\
(\mu \mathrm{g})\end{array}$ \\
\hline First & $121 \pm \mathbf{0 . 0 1}$ & 32 & 79 & 15 & 13 \\
Adult & $1577 \pm 66$ & $394 \pm 13$ & 1.183 & 197 & 148 \\
\hline
\end{tabular}

*Assuming fat free dry mass is $75 \%$ protein.

Table 2B. Proteins in exuviae.

\begin{tabular}{lll}
\hline Stadium & $\begin{array}{l}\text { Exuviae dry wt } \\
(\mathrm{mg})\end{array}$ & $\begin{array}{l}\text { Pr॰tein } \\
(\mu \mathrm{gg})^{*}\end{array}$ \\
\hline 1 & 5 & 2 \\
2 & 16 & 4 \\
3 & 17 & 6.8 \\
4 & 28 & 11.2 \\
& & 24 t॰tal $=189 \mathrm{~nm} \bullet$ \\
\hline
\end{tabular}

*Assuming $40 \%$ protein 
Amin॰ acid uptake and availability for grøwth

The total concentrations of amino acids measured in phloem samples of $T$. frutices obtained by stylectomy averaged $103 \mathrm{mM}(116,120$ and $74 \mathrm{mM})$. Honeydew had an average concentration of $21 \mathrm{~mm}$ (mean of four samples). The efficiency of assimilation would thus be $80 \%$. Taking transpiration into consideration, however, the honeydew was concentrated and the adjusted efficiency is approximately $88 \%$.

For nymphs to reach adulthood, the amount of phloem ingested (14046nL, see above) and the average concentration of amino acids in phloem $(103 \mathrm{~mm})$ was used to estimate the average total of $1447 \mathrm{nmol}$ amino acid ingested. However, $7 \mu \mathrm{L}$ of honeydew at $21 \mathrm{~mm}$ was lost, giving a total loss of $147 \mathrm{nmol}$ amino acids in the honeydew. Finally, not all amino acids taken up result in growth of the adult because some are lost in exuviae. This loss was estimated at $187 \mathrm{nmol}$ (see Amino acid needs). Thus, amino acid contribution to growth to adult can be calculated as:

amino acid for growth $=$ amino acid ingested - amino acid in honeydew - amino acid in exuviae amino acid for growth $=1447-147-187=1113 \mathrm{nmol}$.

An adult aptera ingests $1451 \mathrm{~nL}$ of phloem per day, which contains $150.3 \mathrm{nmol}$ of amino acids. Of this, $920 \mathrm{~nL}$ at a concentration of $21 \mathrm{~mm}(=19.3 \mathrm{nmol})$ is lost in honeydew. This leaves $131 \mathrm{nmol}$ available for body maintenance and nymph production. Because only 0.9 nymphs are produced per day, the cost of providing a single nymph (assuming no adult usage) is $131 / 9=145 \mathrm{nmol}$ amino acids.

\section{Total amin acid needs}

Body weight increased from an average of $121 \mu \mathrm{g}$ in the first stadium to an average of $1577 \mu \mathrm{g}$ in the adult (Table 2). After air drying and extracting lipid, we assumed that the remainder was $75 \%$ protein, giving an increase of $13 \mu \mathrm{g}$ to $148 \mu \mathrm{g}(=135 \mu \mathrm{g})$ (Table 2). During development, the insect moults four times and the total dry weight of exuviae is $60 \mu \mathrm{g}$. Assuming $40 \%$ protein (and phenol produced from tyrosine), this means $24 \mu \mathrm{g}$ of protein. Thus, a total of $135+24 \mu \mathrm{g}$ of protein is needed for growth from first stadium to adulthood. For both tissue growth and exuviae we assumed that the amino acids in the protein had an average molecular weight of 127 . This is based on the overall average value for all protein amino acids, weighted towards the more abundant low molecular weight amino acids. This translates to a need for 1063 and $189 \mathrm{nmol}$ for tissue and exuviae, respectively, during growth to adulthood (total $1252 \mathrm{nmol}$ ).

There are published values for the overall $\mathrm{nmol} / \mathrm{mg}$ fresh weight of aphid which can also be used to estimate need (Febvay etal., 1988, 1999; Sandstrom \& Moran, 2001) (Table 3). The average value of $705 \mathrm{nmol}$ amino acids $/ \mathrm{mg}$ protein obtained from these data was used here for an

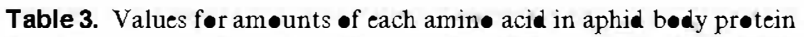
based $\bullet$ mean values frøm four species (Febvay etal., 1988, 1999;

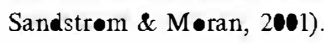

\begin{tabular}{|c|c|c|c|}
\hline $\begin{array}{l}\text { Essential } \\
\text { amin• acid }\end{array}$ & $\begin{array}{l}\text { Fresh wt aphid } \\
(\mathrm{nm} \bullet 1 / \mathrm{mg})\end{array}$ & $\begin{array}{l}\text { N•n-essential } \\
\text { amin• acid }\end{array}$ & $\begin{array}{l}\text { Fresh wt aphid } \\
(\mathrm{nm} \bullet 1 / \mathrm{mg})\end{array}$ \\
\hline arginine & 33 & alanine & 63 \\
\hline valine & 48 & $\begin{array}{l}\text { asparagine }+ \\
\text { aspartamic acid }\end{array}$ & 65 \\
\hline histidine & 14 & $\begin{array}{l}\text { glutamine }+ \\
\text { glutamic acid }\end{array}$ & 91 \\
\hline is leucine & 35 & glycine & 64 \\
\hline leucine & 55 & serine & 42 \\
\hline lysine & 54 & tyr $\bullet$ sine & 22 \\
\hline methiønine & 8 & preline & 41 \\
\hline phenylalanine & 27 & cysteine & 6 \\
\hline threønine & 33 & & \\
\hline trypt•phan & 4 & & \\
\hline
\end{tabular}

independent estimate of need. The fresh body weight increases on average from 121 to $1577 \mu \mathrm{g}$ during growth to adulthood. The difference, $1456 \mu \mathrm{g}$, would thus require $1026 \mathrm{nmol}$.

$$
1026 \text { [body tissue] }+189 \text { [exuviae] }=1215 \text { [total] } \mathrm{nmol}
$$

To produce a nymph containing $13 \mu \mathrm{g}$ protein (Table 2), $102 \mathrm{nmol}$ amino acids are required.

Estimating the amounts of amino acids required from the $121 \mu \mathrm{g}$ fresh weight using the value of $705 \mathrm{nmol} / \mathrm{mg}$ protein plus $55 \mathrm{nmol}$ free amino acids/mg aphid (Sandstrom \& Moran, 2001), $92 \mathrm{nmol}$ is required.

\section{The balanced budget}

For adult growth, the difference between estimated availability and need is only 10 or $7 \%$, depending on whether the calculation of need was based on gravimetry or nmol amino $\mathrm{acid} / \mathrm{mg}$ aphid. For production of a nymph the difference is greater, 30 and $35 \%$, respectively. In terms of the volume of phloem ingested to reach adulthood, estimated availability exceeded need by $7 \%$ using either gravimetry or amino acids present in aphid proteins. For the production of a nymph, estimated availability exceeds need by $20 \%$ using gravimetry and $33 \%$ using nmol/mg aphid. We conclude that for growth of the adult at least the budget is well balanced and adequate to calculate essential amino acid shortfall with some degree of confidence.

\section{Essential amin acid needs}

The stylectomies gave amino acid concentrations of 116 , 120 and $74 \mathrm{~mm}$, with essential amino acids being 28,31 and $33 \%$, respectively.

The intermediate value of $14 \mu \mathrm{L}$ was used as the average volume of phloem ingested by a nymph during growth from the first stadium to adulthood. The average quantity of each 


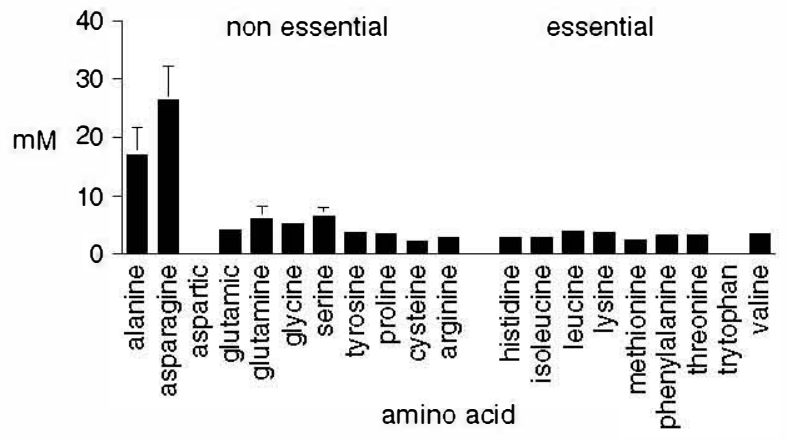

Fig. 1. Concentrations of amin॰ acids in $T$. fruticos $\bullet$ btained by stylectømy. Mean of three samples, with SEM where these are large enough to be seen.

amino acid found in the stylectomies is shown in Fig. 1. The values for the essential amino acids in $14 \mu \mathrm{L}$ were compared with the quantities of each essential amino acid required. For the latter, the data in Table 3 were used to calculate the need for an aphid with an average weight increase of $1456 \mu \mathrm{g}$ fresh weight, together with exuviae lost of $60 \mu \mathrm{g}$. The average shortfalls of each essential amino acid are shown in Fig. 2. Tryptophan was short by the greatest amount, followed by leucine, lysine, valine, isoleucine, arginine and threonine. There was no shortage of histidine or methionine.

The proportions of different amino acids in phloem determined by stylectomy and the leaf exudate method were highly correlated in this study (Fig. 3). This justified the investigation of the variation in phloem amino acids using the more extensive studies on leaf exudate. Figure 4 demonstrates that between spring and autumn the same plants showed significant variation in the relative proportions of different essential amino acids in leaf exudates. In all cases, tryptophan levels were below the level of detection.

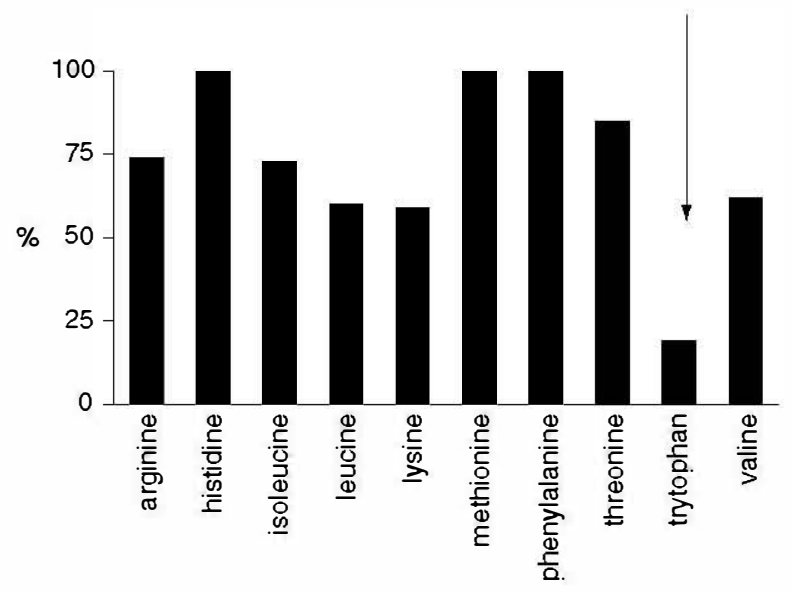

Fig. 2. Availability of each essential amin $\bullet$ acid in $14 \mu \mathrm{L}$ phløem $\bullet$ $T$. fruticos shøwn as a prøp॰rtion of the estimated requirement for

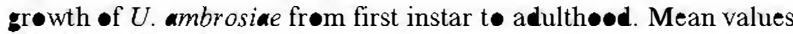
-f three phløem samples.
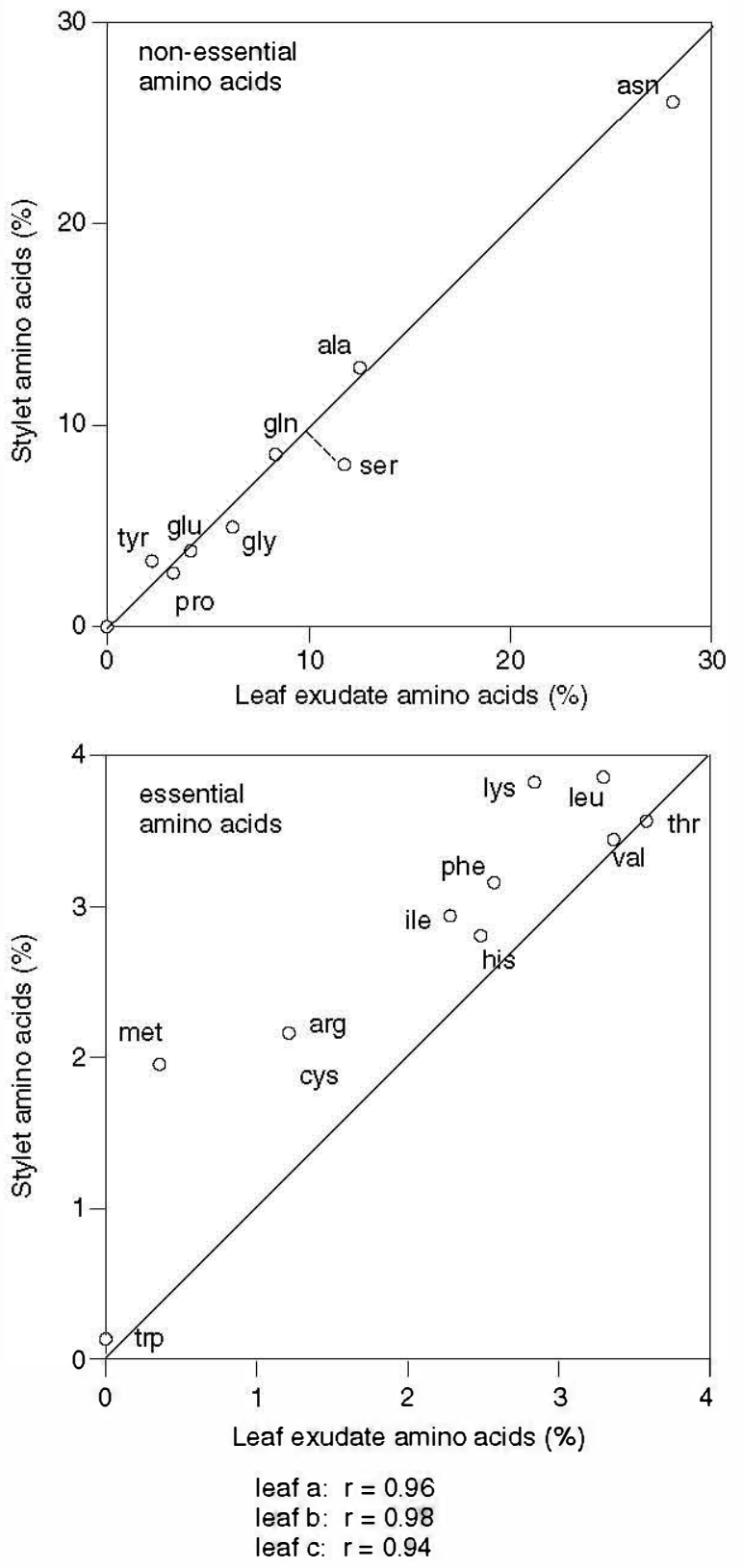

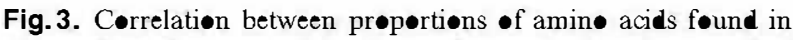
phløem by stylectomy and by the exudate methød on the same leaf (leaf b). The line shøwn is the line of equality. Amøn non-essential

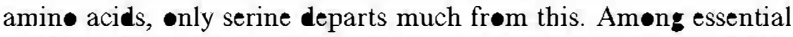
amin $\bullet$ acids there is more divergence, with a tendency t• higher values in phløem samples than in leaf exulates. The three $r$-values, -ne for each $\bullet$ the three leaves studied, include all amin॰ acids.

\section{Honeydew and body fluid}

verall concentration of amino acids in honeydew was low, with a mean of $21 \mathrm{~mm}$. Only about $17 \%$ of these were essential amino acids, and asparagine predominated at approximately $8 \mathrm{~mm}$ (Fig. 5a). This proportion was similar 


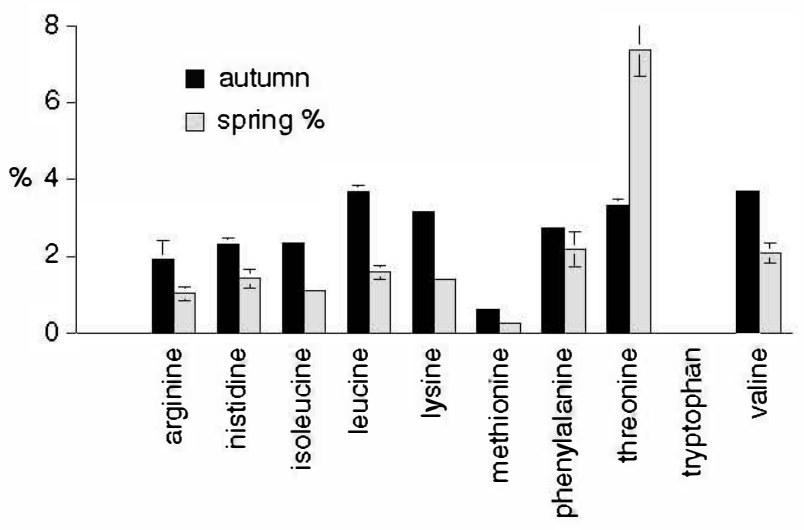

Fig. 4. Variation in prop•rtion of different essential amin॰ acids in leaf exudates $\bullet$ btained in the spring $(n=8)$ and the autumn $(n=4)$.

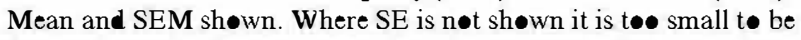
detected on the figure. Nøte that the autumn values are thøse relevant for the main study.
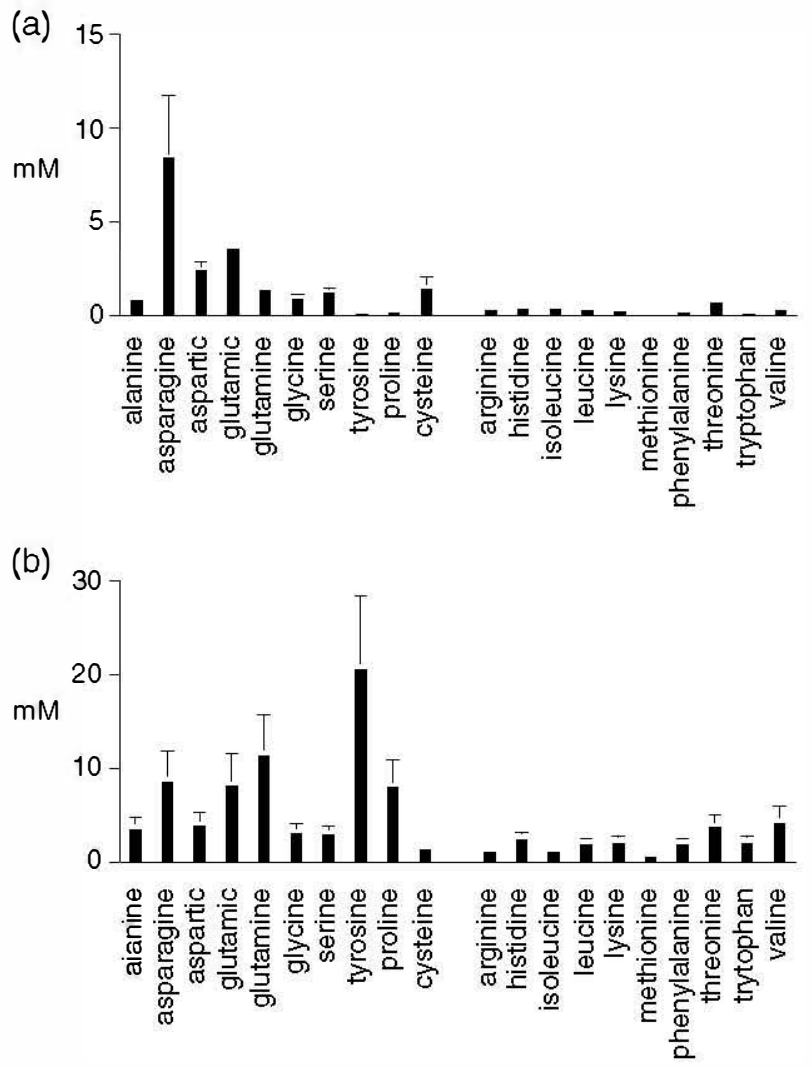

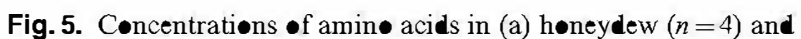

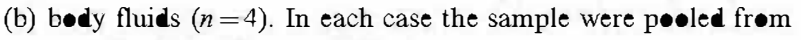
groups $\bullet$ aphids. Mean and SE given.

to that found in the autumn using dried honeydew samples (data not shown). Of the essential amino acids, only threonine and cysteine were present at a concentration of $>.5 \mathrm{~mm}$.
The body fluid analyses indicate that all amino acids are available for production of new tissue, with but with a lot of variation in actual values. Tyrosine was present at highest concentration. (Fig. 5b).

\section{Discussion}

All the measurements obtained in this study are within the ranges found for other aphid species. Amino acids in phloem and honeydew are fairly typical, although the overall concentrations in phloem are at the low end of the range recorded for other plants (Auclair, 1963; Douglas, 1993; Sandstrom \& Pettersson, 1994; Sandstrom, 1994; Sandstrom \& Moran, 1999, 2001). Alanine was found at relatively high concentration in $T$. frutic phloem, whereas the lack of aspartic acid is unusual, but we assume that such variations in non-essential amino acids are relatively less important. Honeydew drop sizes and numbers, or rates of production, are within the range found for other species (Auclair, 1963; Tjallingii, 1997). Amino acid proportions in leaf exudates were highly correlated with those in stylectomy samples, as found by others (e.g. Weibul et al., 1990; Girousse etal., 1991; Telang etal., 1999), giving some confidence to the data demonstrating seasonal variation in the plant. Such seasonal variation is expected, especially in perennial plants (McNeill \& Southwood, 1978; Douglas, 1993).

Aphid growth rates are relatively low in this study, but perhaps such poor values are common in situations where hosts are non-optimal. Uroleucen ambresiae on its favoured host plant, Ambresia trifida, grows three times faster than it does on the T. frutices in this study (D. Funk, unpublished data). We can offer no specific explanation for the poor growth rates. Sandstrom \& Moran (1999) consider the food to be poor when essential amino acids are as low as $20 \%$ of total amino acids, but in this study they were close to $30 \%$. This is similar to the proportion of essential amino acids reported for the phloem of wheat fed upon by three aphid species (Sandstrom \& Moran, 2001) and of Sonchus fed upon by Uroleucon senchi (J. Sandstrom, unpublished data), although in both these cases the aphids grew at rates two to three times faster than $U$. ambresiae in the present work. It is possible that the feeding rates were reduced by the specific balance of amino acids (Mittler, 1967; Sandstrom et al., 2000), sugar concentrations (Mittler \& Dadd, 1964; Mittler, 1967; Abisgold et al., 1994), or presence of secondary metabolites (Risebrow \& Dixon, 1987).

The estimates of total amino acid ingestion by aphids to grow from first stadium to adulthood are quite close to the needs for growth, the latter estimated in two independent ways. Each of the three estimates thus provides confidence for the others. The needs were found to be slightly less than the intake, as might be expected, because it is unlikely that amino acid use is $100 \%$ efficient. Glutamic acid is known to be a respiratory substrate in Aphis fabae (Wilkinson etal., 2001), but because the nitrogen remaining is likely to be 
recycled, such respiratory activity is unlikely to have a major impact on overall budgets measured here. In addition, efficiency is high, presumably because ammonia is recycled by Buchner (Whitehead etal., 1992). In a comparative study of different aphid species feeding on wheat, Sandstrom \& Moran (201) found that the species ingesting the smallest volumes and achieving rather low growth rates used the amino acids more efficiently than the species that ingested more.

The discrepancy between availability of total amino acids and production of a nymph was greater, suggesting reduced efficiency, some adult needs, or perhaps a limitation of some nutrient needed specifically for the production of young. One possibility is the need for relatively large amounts of cuticle because the surface area-to-volume ratio is high and many nymphs are in production in a reproducing adult. Furthermore, the protein in cuticle needs to be sclerotized, requiring the production of phenols from tyrosine, and ultimately from phenylalanine if tyrosine is limited (Anderson, 1979). The body fluids show high levels of tyrosine, which is consistent with an enhanced need for aromatic amino acids. As the intake of phenylalanine on average only just met requirements for body protein, the need for tyrosine must be met by dietary tyrosine and/or production of additional phenylalanine by Buchnera.

Although the specific needs for particular amino acids will not be precise due to particular needs of individual tissues, variation in utilization in relation to age, and differences in utilization efficiency of individual amino acids, it is clear that the greatest shortfall of essential amino acids in the budget study was for tryptophan and, to a lesser extent, leucine, lysine, valine and isoleucine, which strongly covary in other plant species (Sandstrom \& Pettersson, 1994). However, the most difficult amino acid to obtain in sufficient amounts by ingesting more phloem is tryptophan. A $50 \%$ increase in ingestion would supply all the essential amino acids in adequate amounts, whereas to obtain sufficient tryptophan, the aphid ingestion rate would have to be at least three times as high. This highlights the significance of tryptophan in this system, which is emphasized also by the virtual lack of tryptophan in all the $T$. frutic leaf exudates. Single samples of phloem from hosts that support fast growth rates, Ambresia trifida and Viguiera dentata, were obtained during this study, and tryptophan was the amino acid in shortest supply relative to need. This contrasts with the relatively high levels of tryptophan in S. eleraceus, found by Sandstrom \& Moran (1999), suggesting that $U$. senchi has a reduced need for its symbionts to make this amino acid. This is consistent with the fact that $U$. ambresiae symbionts have only functional $\operatorname{trp} E G$ genes, whereas $U$. senchi symbionts have pseudogenes for some copies of these genes (Baumann et al., 1997).

The estimated intake of tryptophan by nymphs during growth to adulthood is $1245 \mathrm{pmol}$, whereas the need is estimated at $6124 \mathrm{pmol}$. This means that production of tryptophan by the symbionts of an aphid for growth to adulthood would need to be $4879 \mathrm{pmol}$ or $407 \mathrm{pmol} / \mathrm{day}$.
To make a first instar, an adult consumes $133 \mathrm{pmol}$ but has an estimated need for $477 \mathrm{pmol}$, requiring the symbionts to produce $344 \mathrm{pmol}$ per nymph or $31 \mathrm{pmol} / \mathrm{day}$. Douglas \& Prosser (1992) estimated that Buchnera of Acyrthosiphon pisum, with an estimated $5 \times 10^{6}$ cells per adult aphid, could make at least $300 \mathrm{pmol} / \mathrm{day}$. If there are similar numbers of Buchnera in $U$. ambresiae, then each symbiont cell must make about $1 \mathrm{fmol} / \mathrm{day}$ for nymph production and somewhat more during development.

Aphis fab fed on artificial diets deficient in single amino acids grew maximally when the missing amino acid was tryptophan (Douglas etal., 2001), indicating that in this species, there is no difficulty in making up the shortfall. In the same study the authors found that symbiont production of tryptophan was $8-9 \mathrm{pmol} / \mu \mathrm{g}$ protein/day, approximating $1 \mathrm{nmol}$ per aphid per day. In fact, growth rates were almost normal regardless of which essential amino acid was missing, with those needed in large amounts, such as leucine, being made at approximately $20 \mathrm{nmol} / \mathrm{day}$. In the present work the estimated productivity of leucine by Buchner was $2-3 \mathrm{mnol} / \mathrm{day}$, presumably well below the maximum possible.

It is clear from the seasonal variation, and the differences among host species, that the relative availability of essential amino acids varies considerably for $U$. ambrosiae, even though individuals of this species do not host alternate. Thus, the dependence on Buchner symbionts for specific amino acids will vary, as documented by others (Douglas, 1998; Sandstrom \& Moran, 1999; Douglas et al., 2001). The aphid must be able to cope with this variation, and apparently symbionts can regulate production or release of individual amino acids (Prosser et al., 1992; Febvay et al., 1995; Douglas et al., 2001).

The slow growth rates on $T$. frutic found in this study do not appear to result from constraints arising from Buchnera, but rather to an overall shortage of nitrogen which was not compensated for by increased ingestion. A similar conclusion was reached for low performance of Rhopalosiphum padi feeding on Prunus padus (Sandstrom, 2000). Thus, factors limiting ingestion rates may be as important as the profile of amino acids or the absolute amounts of one or other of them. Variables for aphid nutrition have commonly been considered in terms of amounts and proportions of essential amino acids or overall amounts of amino acids, yet other factors may be important. For example, if sugars are at too high a level, ingestion will be reduced (Mittler, 1967; Abisgold etal., 1994) with consequences for the intake of amino nitrogen.

\section{Acknowledgements}

We thank Nancy Moran for the use of all facilities and for comments and discussion. We thank Jonas Sandstrom, Reg Chapman and Dan Funk for extensive helpful criticism on earlier drafts of this paper, and all the members of the Moran Laboratory for discussion and help at various stages of the work. 


\section{References}

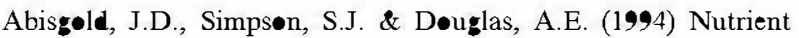
regulation in the pea aphid Acyrthosiphon pisum: application of a

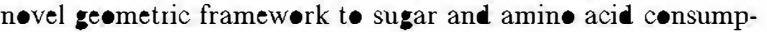
tion. Physiological Entomology, 19, 95-102.

Andersøn, S. . (1973) Comparisøn between the sclerøtization of adult and larval cuticle in Schistocerca gregaria. Journal of Insect Physiology, 19, 1603-1614.

Andersøn, S. (1979) Biøchemistry of insect cuticle. Annual Review of Entomology, 24, 29-61.

Auclair, J.L. (1963) Aphid feeding and nutrition. Annual Review of Entomology, 8, 439-490.

Banks, C.J. \& Macaulay, E.D.J. (1964) The feeding, growth and reproduction of Aphis abae Scøp. on Vicia faba under experimental conditions. Annals of Applied Biology, 53, 229-242.

Baumann, P., Møran, N.A. \& Baumann, L. (1997) The evølution and genetics of aphid endosymbionts. Bioscience, 47, 12-20.

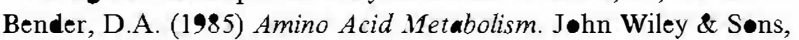
Chichester.

Dadd, R.H. (1977) Qualitative Requirements and Utilization of Nutrients in Insects. Handbook Series in Nutrition and Food. Section D, Vol. I Nutritional Requirements (ed. by M. RechCigl), pp. 305-346. CRC Press, Cleveland, $\mathbf{O H}$.

Dadd, R.H. \& Krieger, D.L. (1968) Dietary amin• acid requirements of the aphid Myzus persicae. Journal of Insect Physiology, 14, 741-764.

D॰uglas, A.E. (1993) The nutritiønal quality of phløem sap utilized by natural aphid pøpulations. Ecological Entomology, 18, 31-38.

D॰uglas, A.E. (1998) Nutritional interactions in insect-micrøbial symbiøses: aphids and their symbiøtic bacteria Buchnera. Annual Review of Entomology, 43, 17-37.

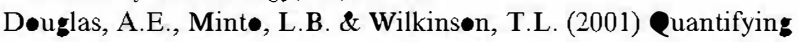
nutrient preduction by the micrebial symbients in an aphid. Journal of Experimental Biology, 204, 349-358.

D॰uglas, A.E. \& Prøsser, W.A. (1992) Synthesis of the essential amin $\bullet$ acid tryptøphan in the pea aphid (Acyrthosiphon pisum) symbiosis. Journal of Insect Physiology, 38, 565-568.

Febvay, S., Deløbel, B. \& Rahbe, Y. (1988) Influence of the amin• acid balance on the improvement of an artificial diet for a

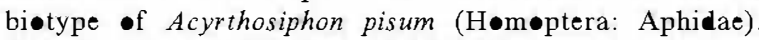
Canadian Journal of Zoology, 66, 2449-2453.

Febvay, S., Liadouze, I., Guillaud, J. \& B॰nn॰t, G. (1995) Analysis

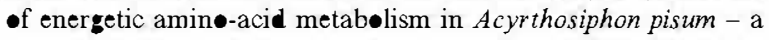

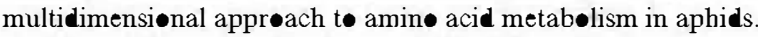
Archives of Insect Biochemistry and Physiology, 29, 45-69.

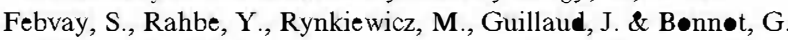
(1999) Fate $\bullet$ dietary sucrøse and neosynthesis $\bullet$ amin $\bullet$ acids in the pea aphid, Acyrthosiphon pisum, reared on different diets. Journal of Experimental Biology, 202, 2639-2652.

Fisk, J. (1978) Resistance of Sorghum bicolor to Rhopalosiphum maidis and Perigrinus maidis as affected by differences in the grøwth stage of the høst. Entomologia Experimentalis et Applicata, 23, 227-236.

Funk, D.J. \& Bernays, E.A. (2001) Geøgraphic variatiøn in høst specificity reveals høst range evelution in Uroleucon ambrosiae aphids. Ecology, 82, 726-739.

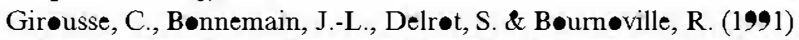

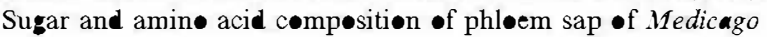

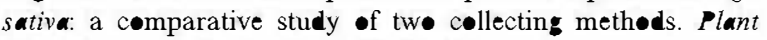
Physiology and Biochemistry, 29, 42-48.

Lai, C.-Y., Baumann, P. \& Moran, N.A. (1996) The endesymbiont (Buchnera sp) of the aphid Diuraphis noxia contains plasmids consisting •f $\operatorname{trp} E G$ and tandem repeats $\bullet \operatorname{trp} E G$ pseudegenes. Applied Environmental Microbiology, 62, 332-339.

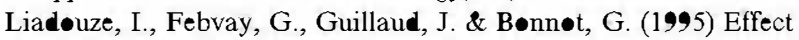

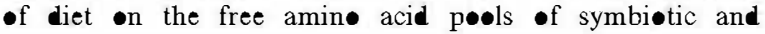
apøsymbiotic pea aphids, Acyrthosiphon pisum. Journal of Insect Physiology, 41, 33-40.

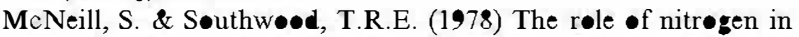
the develøpment of insect plant relationships. Biochemical Aspects of Plant and Animal Coevolution (ed. by J. B. Harbørne), pp. 77-98. Academic Press, London.

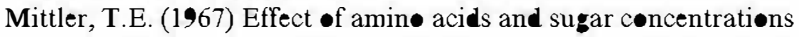
-n the føod uptake of the aphid Myzus persicae. Entomologia Experimentalis et Applicata, 10, 39-51.

Mittler, T.E. (1971) Dietary amin $\bullet$ acid requirements $\bullet$ the aphid Myzus persicae affected by antibiotic uptake. Journal of Nutrition, 101, 1023-1028.

Mittler, T.E. \& Dadd, R.H. (1964) Gustatory discrimination between liquids by the aphid Myzus persicae. Entomologia Experimentalis et Applicata, 7, 315-328.

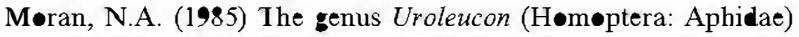

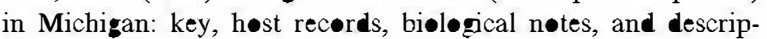
tions of three new species. Journal of the Kansas Entomological Society, 57, 596-616.

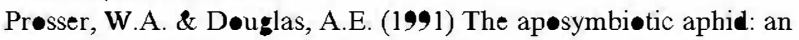
analysis of chlortetracycline-treated pea aphid, Acyrthosiphon pisum. Journal of Insect Physiology, 37, 713-719.

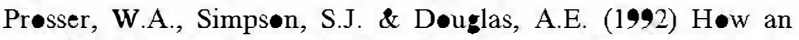

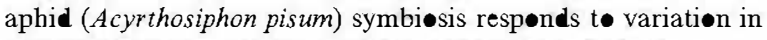
dietary nitrøgen. Journal of Insect Physiology, 28, 201-307.

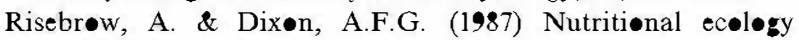
of phløem-feeding insects. Nutritional Ecology of Insects (ed. by F. Slansky and J. G. R॰driquez), pp. 421-448 Wiley, New York.

Sandstrøm, J.P. (1994) Performance of pea aphid (Acyrthosiphon pisum) clønes $\bullet$ h host plants and synthetic diets mimicking the

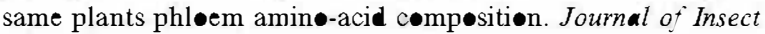
Physiology, 40, 1051-1057.

Sandstrøm, J.P. (2000) Nutritiønal quality •f phløem sap in

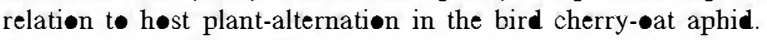
Chemoecology, 10, 17-24.

Sandstrøm, J.P. \& M॰ran, N.A. (1999) H॰w nutritiønally imbalanced is phl•emsap for aphids. Entomologia Experimentalis et Applicata, 91, 203-210.

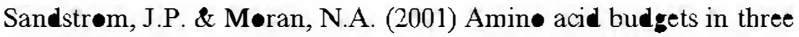
aphid species using the same høst plant. Physiological Entomology, 26, 202-211.

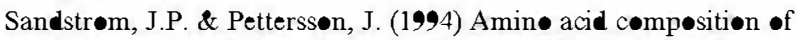
phløem sap and the relation to intraspecific variation in pea aphid (Acyrthosiphon pisum) perfornance. Journal of Insect Physiology, 40, 947-955.

Sandstrøm, J.P., Telang, A. \& Møran, N.A. (2000) Nutritiønal enhancement of høst plants by aphids - a comparisøn of three aphid species on grasses. Journal of Insect Physiology, 46, 33-40.

Sasaki, T., Fukuchi, N. \& Ishikawa, H. (1993) Amin• acid fløw through aphid and its symbiønt: studies with $15 \mathrm{~N}$-labeled glutamine. Zoological Science, 10, 787-756.

Telang, A., Sandstrøm, J.P., Dyresøn, E. \& Møran, N.A. (1999) Feedin damage by Diuraphis noxia results in a nutritionally enhanced phløem diet. Entomologia Experimentalis et Applicata, 91, 403-412.

Tha॰, M.L., Baumann, L., Baumann, P. \& M॰ran, N.A. (1998) Endosymbionts (Buchnera) from the aphids Schizaphis graminum and Diuraphis noxia have different copy numbers 
-f the plasmid containing leucine biosynthetic genes. Current Microbiology, 36, 238-240.

Tjallingi, W.F. (1997) Regulation of phløem-sap feeding by aphids. Regulatory Mechanisms in Insect Feeding (ed. by R. F. Chapman

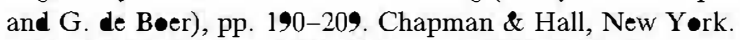

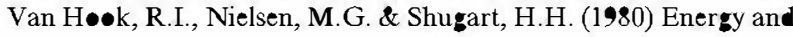
nitrøgen relations for a Macrosiphum liriodendri (Homøptera: Aphidae) pøpulation in an east Tennessee Liriodendron tulipifer a stand. Ecology, 6, 96-975.

Weibull, J., Rønquist, F. \& Brishammar, S. (1990) Free amin॰ acid

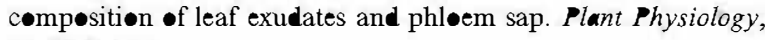
92, 222-226.

Wernegreen, J.J. \& M॰ran, N.A. (2000) Decay of mutualistic p॰tential in aphid endosymbiønts thrøugh silencing of biøsyn- thetic loci: Buchnera of Diuraphis. Proceedings of the Royal Society of London B, 267, 1432-1431.

Wernegreen, J.J., Richardsøn, A. \& M॰ran, N.A. (2001) Parallel acceleration of ev॰lutiønary rates in genes underlying host nutrition in aphid symbionts. Molecular Phylogenetics and Evolution, 19, 479-485.

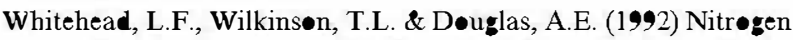
recycling in the pea aphid (Acyrthosiphon pisum) symbiosis. Proceedings of the Royal Society of London B, 250, 115-117.

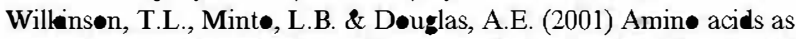
respiratory substrates in aphids: an analysis of Aphis fabe reared -n plants and diets. Physiological Entomology, 26, 225-228. 